\title{
PENGELOLAAN BENCANA BERBASIS KAPASITAS LOKAL DI KAWASAN GUNUNG KELUD PASCA ERUPSI TAHUN 2014 (STUDI ETNOGRAFI DI KAWASAN RAWAN BENCANA GUNUNG KELUD KABUPATEN KEDIRI)
}

\author{
Windiani ${ }^{1}$, I.B. Wirawan ${ }^{2}$ dan Sutinah ${ }^{3}$ \\ ${ }^{1}$ UPT PMK Sosial Humaniora, FBMT, Institut Teknologi Sepuluh Nopember \\ 2, 3 Jurusan Sosiologi, FISIP, Universitas Airlangga \\ email: windianiits@gmail.com
}

\begin{abstract}
ABSTRAK
Penelitian ini bertujuan mengeksplorasi keterlibatan berbagai pihak dalam pengelolaann bencana di kawasan Gunung Kelud pasca erupsi tahun 2014. Penelitian dilakukan di KRB Gunung Kelud Kabupaten Kediri dengan informan yang berasal dari institusi pemerintah (BPBD), NGO Jangkar Kelud dan Masyarakat Lokal. Pendekatan etnografi digunakan untuk mengeksplor fenomena sosial budaya yang terjadi di wilayah studi. Teknik pengumpulan data menggunakan participant observation, In depth interview dan penelusuran dokomen serta analisis data dilakukan secara deskriptif-analitis. Hasil penelitian menunjukkan bahwa pasca erupsi tahun 2014 upaya pengelolaan bencana yang dilakukan lebih mengndayagunakan kapasitas lokal yang ada di kawasan rawan bencana Gunung Kelud. Saat ini kegiatan pengelolaan bencana yang dilakukan adalah mitigasi dan membangun kesiapsiagaan masyarakat di KRB Gunung Kelud. Praktik pengeleloaan bencana dilakukan secara kolaboratif antara masyarakat lokal, BPBD dan LSM Jangkar Kelud. Salah satu program yang dikembangkan adalah 'sister village' (desa bersaudara). Penelitian ini juga mengungkap adanya dinamika dalam pengembangan program sister village. Program ini didukung masyarakat dan tokoh-tokoh lokal termasuk orang-orang yang masih kokoh dalam memegang nilai-nilai adat, tradisi, sehingga program sister village dianggap sebagai model penanggulangan bencana yang lebih mengakar secara sosio-kultural dan selanjutnya dapat digunakan sebagai referensi dalam mengembangkan model pengelolaan bencana berbasis kapasitas lokal di Indonesia. Di sisi lain penolakan (resistens) dari warga turut mewarnai pengembangan program sister village. Adanya anggapan bahwa 'sister village' hanya sebatas program dengan dana kegiatan yang sudah dianggarkan, sehingga sebagian warga menolak untuk mengikuti kegiatan yang dilaksanakan pemerintahan desa dan difasilitasi BPBD.

Kata Kunci: Pengelolaan bencana, Kapasitas Lokal, Kawasan Rawan Bencana, Sister Village
\end{abstract}

\section{PENDAHULUAN}

Studi ilmu sosial dalam ranah kebencanaan dari berbagai perspektif sudah banyak dilakukan di berbagai negara di dunia, termasuk di Indonesia seperti Sussane Hofman dan Oliver-Smith (Hoffman \& Smith, 2002), Ahimsa-Putra dan Agus Indiyanto (Indiyanto, 2012), Arifin dan Chusairi (Arifin \& Chusairi, 2015) dan sebagainya. Hasil kajian pada umumnya lebih menekankan dimensi sosio kultural dengan fokus pada peran modal sosial dan penggalian kearifan lokal dalam mengurangi risiko bencana. Meski sudah dikaji secara luas, namun kajian yang mengeksplor pengelolaan bencana berbasis kapasitas lokal di kawasan rawan bencana masih terbatas sehingga dipandang penting dan menarik untuk dilakukan.

Studi ini bertujuan mengekplorasi pengelolaan bencana berbasis kapasitas lokal di kawasan gunung Kelud pasca erupsi tahun 2014 dengan fokus kajian pada pengembangan desa bersaudara (sister village) di Kawasan Rawan Bencana (KRB radius $10 \mathrm{~km}$ dari Gunung Kelud) di wilayah 
Kabupaten Kediri. Studi ini menggunakan pendekatan etnografi dengan perangkat konseptual ranah dan modal dari Pierre Bourdieu dan teorisasi bencana dari Antropolog Oliver Smith serta berbagai kajian terdahulu yang relevan.

Ada beberapa alasan mengapa studi ini dipandang penting dan menarik dalam konteks kekinian: Pertama, kejadian bencana dalam satu dasawarsa semakin meningkat baik skala maupun intensitasnya yang menimbulkan berbagai kerusakan dan korban jiwa maupun. Berdasarkan laporan World Risk Report (2012) dari tahun 2002 hingga 2011 telah terjadi 4.130 bencana di seluruh dunia yang mengakibatkan lebih dari 1 juta orang meningggal dan kerugian material yang mencapai US\$ 1,195 triliun. Kedua, secara geografis posisi Indonesia yang terletak di antara lempeng Erusia dan lempeng Australia serta berada di jalur rink fire (cincin api) telah menempatkan Indonesia sebagai negara rawan bencana alam di dunia. Sebagian besar wilayah Indonesia, memiliki ancaman bencana gempa bumi dan tsunami, letusan gunung berapi, banjir, tanah longsor. Di wilayah Jawa Timur, hampir sebagian besar merupakan daerah rawan bencana. Berdasarkan data yang dilansir Badan Penanggulangan Bencana Daerah Propinsi Jawa Timur (2016), 32 dari 38 kabupaten masuk dalam wilayah rawan bencana banjir, longsor, gempa dan tsunami, ditambah 7 gunung berapi aktif di Jatim yang sewaktu waktu meningkat aktivitasnya, yaitu gunung Kelud di kabupaten Kediri-Blitar-Malang,Batu, gunung Arjuno-Welirang di Malang, gunung Bromo di Probolinggo, gunung Semeru di Lumajang, gunung ljen di Banyuwangi, gunung Raung di Jember dan gunung Lemongan di Lumajang (BNPB, 2016). Ketiga, setiap terjadi bencana seringkali memunculkan gugatan terhadap peran dan tanggung jawab dari berbagai pihak yang terlibat dalam penanggulangan bencana. Peran dan tanggung jawab ini bukan hanya diletakkan pada upaya penanggulangan dampak bencana, namun lebih pada upaya membangun bangsa yang tangguh dalam menghadapi bencana secara berkelanjutan.

Studi ini juga didasari semakin maraknya minat kajian ilmu sosial dalam isu lingkungan kebencanaan yang menjadi bagian isu global terutama pasca diberlakukannya kebijakan dalam penanggulangan bencana di Indonesia dan implementasinya di berbagai daerah di era otonomi. Lahirnya Undang-Undang Republik Indonesia No 24 tahun 2007 tentang Penanggulangan Bencana dan PP No 21 tahun 2008 tentang Penyelenggaraan penanggulangan bencana di tanah air telah memberi ruang bagi pengembangan tata kelola bencana berbasis kapasitas lokal. Model pengelolaan ini mensyaratkan keterlibatan bukan saja pemerintah yang direpresentasikan Badan Nasional Penanggulangan Bencana (BNPB), Badan Penanggulangan Bencana Daerah (BPBD), namun juga masyarakat lokal, LSM/NGO, swasta.dan pihak-pihak yang concern terhadap isu-isu dalam pengelolaan bencana. Pola pengelolaan bencana yang mengandalkan peran tunggal (misalnya hanya pemerintah saja) untuk konteks kekiniian tidak lagi relevan, mengingat bencana yang terjadi pun bersifat kompleks dan multidimensional, sehingga dibutuhkan peran, tanggung jawab dan keterlibatan berbagai pihak dalam pengelolaannya. Untuk itu studi tentang Pengelolaan Bencana Berbasis Kapasiats Lokal di Kawasan Gunung Kelud Pasca Erupsi tahun 2015 dengan lokus kajian di KRB 2 wilayah kabupaten Kediri menemukan konteksnya.

\section{EKSPLORASI PENELITAN TERDAHULU}

Kajian terdahulu tentang pengelolaan bencana di kawasan gunung berapi sudah banyak dilakukan dari berbagai disiplin keilmuan seperti; sosiologi, anthropologi, geografi, dan studi pembangunan. Isu-isu dalam pengelolaan bencana di kawasan gunung berapi selalu menjadi wilayah kajian yang menarik, mengingat di Indonesia yang memiliki lebih dari 150 gunung berapi aktif dan puluhan gunung yang telah meletus, menghancurkan peradaban dan membunuh manusia. Namun faktanya manusia kembali datang dan hidup di wilayah yang sama, beradaptasi kembali dan membangun kehidupannya di tempat yang sama. Payson D Sheet (2002) menemukan beberapa bentuk resiliensi pada masyarakat kuno di dekat gunung berapi. Masyarakat Indian di gunung Arenal Costa rica mengembangkan system sosial egaliter sebagai ebntuk resiliensi dengan asusmsi bahwa 
masyarakat egaliter memiliki kemampuan lebih cepat dalam pengambilan keputusan untuk menghindari letusan. Masyarakat tersebut mengembangkan pola pertanian heterokultur sehingga memungkinkan menjadi cadangan pangan saat mengungsi (Oliver Smith dan Susane Hofman, 2004).

Sementara, persepsi masyarakat terhadap letusan gunung Merapi sebagai pusat kosmologis dipelajari peneliti antara lain; Ahimsa-Putra, 2002; Laksono, 2009,dan Humaidi, 2015 (Lubis, 2000). Ahimsa (2000) membagi tafsir terhadap gunung berdasarkan aktor, mulai dari raja, paranormal, abdi dalem, ulama sampai dengan rakyat dusun Turgo. Hasil studi menunjukkan bahwa tafsir dari banyak aktor tersebut berkisar pada dua hal; letusan sebagai peringatan atau pelajaran, cobaan serta sebagai takdir (Indiyanto, 2012).

Humaedi (2015:198) dalam penelitiannya terkait Merapi memperlihatkan pola adaptasi berbeda pada kondisi alam berbeda. Warga dusun Plalangan yang dalam sejarahnya belum pernah terkena letusan, meyakini letusan Merapi tidak pernah menimpa mereka, meski hanya berjarak sekitar $5 \mathrm{~km}$ dari puncak. Masyarakat Gemer yang mengalami kehancuran karena geger 1930 melihat Merapi sebagai berkah, bukan ancaman. Namun mereka juga merangkum pengetahuan mengenai tanda-tanda alam bila Merapi akan meletus serta bahaya mengarah ke permukiman mereka antara lain: hewan liar sudah turun ke permukiman, udara semakin panas serta adanya thatit malang(Humaedi, 2015).

Menurut Michhael Dove (2006) mempelajari gunung berapi, khususnya di pulau Jawa tidak hanya penting dalam kaitannya mempelajari ekologi manusia, namun lebih dari itu, Ternyata gununggunung berapi di Jawa merupakan sumber bagi kehidupan di samping bencana, serta erat kaitannya dengan berbagai peristiwa yang pernah terjadi di masa lampau, lebih lanjut Dove merujuk C. Geertz (1983) yang berpendapat bahwa sepanjang sejarah di pulau Jawa, gunung-gunung berapi telah munjadi sumber kehidupan, baik tanah maupun air yang diberikan termasuk abu dan asapnya. Sebaliknya, gunung berapi juga sumber kematian karena gas beracun, awan panas, lahar banjir lumpur. Oleh karena itu kesuburan tanahnya ada kecenderungan bahwa semakin dekat dengan gunung berapi tingkat kepadatan penduduk Jawa semakin tinggi.

Kelman dan Mather (2008) menemukan pasca erupsi Pinatubo 1991, masyarakat di sekitarnya menunjukkan bagaimana peluang vulkanik dapat digunakan untuk mata pencaharian yang berkelanjutan. Pendekatan hidup bersama risiko dan manfaat vulkanik dapat diadopsi dan diimplementasikan sebagai bagian integral dari mengubah persepsi gunung api dan mengelola situasi krisis dan non krisis terkait gunung berapi. Meskipun diakui bahwa pendekatan penghidupan yang berkelanjutan bukanlah obat mujarab (panacea) yang menyelesaikan semua masalah penghidupan di kawasan rawan bencana (KRB). Keragaman mata pencaharian dan pengalihan mata pencaharian pada lokasi lainnya membantu dalam hidup bersama gunung api (Kelman \& Mather, 2008).

Yasin Yusup (2014:59-77) mengekplorasi bagaimana komunitas di KRB Merapi berupaya hidup bersama risiko bencana dengan yakni beradaptasi dengan letusan yang terus berevolusi dengan mengandalkan jejeraing sosial dan memperluasnya dengan komunitas lain di luar KRB. Jejaring sosial bisa berfungsi menjembatani isolasi suatu wilayah sehungga kedekatan dengan sumber ancaman tidak otomatis meningkatkan kerentanan dan risiko bencana bagi komunitas di KRB Merapi (Yusup, 2014).

Donovan (2016:15-16) dalam penelitiannya Geopower: Reflection On Critical Geography Of Disaster menggagas pentingnya upaya pengurangan risiko bencana (gunung berapi) dengan melibatkan berbagai ahli. Pengurangan risiko bencana merupakan gabungan dari aktor, asosiasi strategi dan konsep. Adanya dinamika kekuasaan dan pengetahuan (Donovan, 2010, Gailard and Mercer 2013, Hayashi and Hudges, 2013) dkk. bukan hanya menyangkut scientific (pengetahuan ilmiah) dan pengetahuan lokal, tetapi juga terkait perbedaan dengan komponen yang lain dalam bencana(Donovan, 2016).

Berbagai kajian empiris terkait pengelolaan bencana di kawasan gunung berapi di berbagai negara seperti yang telah diuaraikan sebelummnya, juga dapat ditemui dari berbagai kajian terkait gunung berapi Kelud. Penelitian Rustinsyah dan Muhammad Adib (2013) mengungkap Model 
strategi pengelolaan lingkungan berbasis komunitas lokal untuk mencegah dan menghadapi bencana di desa-desa sekitar daerah lereng gunung Kelud Kabupaten Kediri. Dalam penelitiannya menyatakan bahwa kerusakan lingkungan di kawasan rawan bencana di kawasan lereng Kelud bukan hanya disebabkan faktor alam, namun juga disebabkan perilaku manusia. Hasil penelitian menujukkan bahwa strategi menjaga, mengelola lingkungan di Desa Besowo berbatasan langsung dengan kawasan hutan dan merupakan daerah lereng gunung dilakukan secara individu maupun lembaga baik lembaga pemerintah seperti; Dinas perkebunan, Perhutani, pemerintah desa dan Lembaga Swadaya Msyarakat Jangkar Kelud.

Pasca eruspi 2014, berbagai penelitian dilakukan antara lain Wardani, dkk (2014) menunjukkan dampak gunung berapi Kelud pasca erupsi 2014 pada kondisi sosial ekonomi Masyarakat di wilayah terdampak radius $10 \mathrm{~km}$ dari kawah gunung Kelud di kabupaten Blitar, Kediri dan Malang. Kondisi perekonomian sempat terhenti sementara karena sumber penghidupan seharihari rusak akibat erupsi; namun sector pariwisata menjadi salah satu pembangkit ekonomi lokal yang didurung oleh antusiasme untuk berwisata di kawasan bencana; pertambangan dan hutan menjadi pembangkit ekonomi. Sementara Studi yang dilakukan Desy Kurniawati, dkk (2014) fokus pada kesiapsiagaan tanggap bencana masyarakat desa Ngancar Kediri terhadap erupsi Kelud tahun 2014. Temuannya menunjukkan bahwa masyarakat di KRB 3 memiliki tingkat partisipasi rendah namun memiliki tingkat pemahaman dan pengalaman tentang bencana yang tinggi dibandingkan masyarakat di KRB 2 dan 1. Rendahnya tingkat partisipasi masyarakat di KRB 3 dikarenakan mereka merasa sudah mampu mitigasi diri mereka sendiri dengan pemahaman dan pengalaman yang mereka miliki. Sementara Studi kasus yang dilakukan Ajeng Rahayu Pratiwi (2015) menganalisis perubahan sosial pada masyarakat Desa Pandansari pasca bencana erupsi gunung Kelud dengan melihat adanya perubahan perilaku dan kehidupan sosial masyarakat(Sartohadi \& Pratiwi, 2014).

Danang Arifin dan Chusairi (2015) melakukan studi deskriptif tentang pengurangan risiko bencana berbasis komunitas di daerah terdampak erupsi gunung Kelud. Pengurangan risiko bencana berbasis komunitas dijelaskan sebagai sebuah pendekatan yang mendorong komunitas akar rumput dalam mengelola risiko bencana lokal setempat. Hasil penelitian menunjukan bahwa Jangkar Kelud mulai melakukan kegiatan kebencanaan ke masyarakat sejak tahun 2008, dengan melakukan lokalatih mengenai pengetahuan dan manajemen bencana. Jangkar Kelud melakukan kegiatannya tidak sendiri melainkan dengan bantuan dari KAPPALA, PSMB UPN Veteran, UNDP, CSR Sampoerna, tokoh masyarkat, perangkat desa, serta masyarakat sendiri. Kegiatan PRBBK di lingkar Kelud pun tidak lepas dari beberapa faktor penghambat seperti masalah dana, koordinasi, serta sikap masyarakat pada kegiatan Jangkar Kelud yang dinilai sia-sia (Arifin \& Chusairi, 2015).

Berdasarkan fakta-fakta dan sejumlah kajian terdahulu yang telah diuraikan sebelumnya mengkaji tentang pengelolaan bencana di kawasan gunung berapi termasuk Gunung Kelud memberikan gambaran bahwa betapa sangat tidak memadai jika pilihan atas teori dan pendekatan yang bersifat tunggal. Bencana bersifat kultural dan dipengaruhi kondisi sosial budaya dan politik yang terjadi dalam masyarakat di mana peristiwa itu terjadi. Dibutuhkan pendekatan yang bersifat holistik untuk mengekaplorasi berbagai fenomena sosial budaya dan isu-isu dalam pengelolaan bencana di wilayah studi. Untuk itu pendekatan etnografi dengan perangkat konseptual dari Bourdieu tentang Ranah dan modal serta dan teorisasi tentang bencana dari oliver Smith dipandang lebih relevan digunakan.

\section{KAJIAN TEORITIS}

Studi ini berupaya mengeksplorasi pola pengelolaan bencana di tingkat akar rumput dengan fokus kajian pada pengelolaan bencana berbasis kapasitas lokal di KRB 2 Gunung Kelud pasca erupsi tahun 2014 di kabupaten Kediri. Aktor dalam tata kelola bencana dalam studi ini meliputi masyarakat lokal, pemerintah, dan NGO (LSM) yang terlibat dalam tata kelola bencana di kawasan rawan bencana gunung Kelud yang mencakup wilayah administratif kabupaten Kediri, kabupaten 
Blitar dan kabupaten Malang. Studi ini menggunakan perangkat konseptual Pierre Bourdieu (1986) tentang Arena, Modal dan Kekuasaan; konsep tentang bencana dari Oliver Smith (Hoffman \& Smith, 2002), tata kelola bencana, serta konsep dan proposisi dari studi terdahulu yang relevan. Sementara pendekatan etnografi digunakan untuk mengeksplorasi fenomena sosial budaya yang terjadi terkait permasalahan yang dikaji di wilayah studi (Windiani \& Rahmati, 2016).

Konsep arena (field) (Bourdieu, 1986) dipahami sebagai medan perebutan, pergulatan dan perjuangan dalam rangka mentransformasikan atau mempertahankan arena kekuasan (field of force). Aktor atau agen tidak hidup di ruang kosong, tetapi selalu terlibat dalam dunia sosial. Jika habitus adalah sejarah yang menubuh dalam agen, maka dunia sosial (arena) adalah sejarah yang diobjektifikasi dalam benda dan institusi, dalam bentuk struktur dan mekanisme (Bourdieu, 1986).

Arena adalah ruang beroperasinya habitus dan reproduksi modal. Dalam konsteks studi, arena digunakan untuk mengkonseptualisasikan tata kelola bencana sebagai arena (medan) sosial karena di dalamnya para pelaku (aktor) saling bertindak melalui hubungan-hubungan sosial di antara mereka. Di dalamnya terdapat kiat-kiat atau strategi aktor dalam melaksanakan dan atau mengalami kuasa, sehingga berpengaruh terhadap posisi masing-masing. Tata kelola bencana dapat dipahami sebagai arena perebutan, pergulatan dan perjuangan bagi aktor-aktor dalam memperoleh dan mempertahan posisi. Tata kelola bencana merupakan ruang beroperasinya habitus dan reproduksi modal. Dalam arena tersebut ada relasi dalam bentuk kerja sama dan persaingan antara aktor yang berperan dalam pengelolaan bencana yang meliputi masyarakat lokal, aparat pemerintah, LSM dan dan swasta. Masing-masing pihak berusaha menguatkan dan mempertahankan posisinya dengan berbagai strategi. Strategi dalam konteks studi dimaksudkan untuk menjelaskan cara aktor-aktor dalam membangun relasi kuasanya dalam tata kelola bencana di kawasan lereng Kelud. Bagaimana strategi yang digunakan dan kapasitas dan sumber daya (modal) yang diperjuangkan masyarakat lokal, pemerintah, LSM dan pihak swasta dalam membangun kekuatan dan kesiapsiagaan dalam dalam pengelolaan bencana inilah yang perlu diuji secara empiris di wilayah studi.

Pengelolaan bencana di kawasan lereng Gunung Kelud dapat dipandang sebagai konsekuensi dari kebijakan yang dilakukan negara pada skala nasional melalui UU No 24 Tahun 2007 tentang Penanggulangan Bencana dan PP No 21 Tahun 2008 tentang Penyelenggaraan Penanggulangan Bencana di Indonesia. Kebijakan tersebut ditujukan untuk menaggulangi bencana yang terjadi di berbagai wilayah di Indonesia dan dalam pengimplementasiannya bukan hanya dilakukan oleh pemerintah pusat, namun melibatkan institusi lokal seperti masyarakat lokal, pemerintah daerah, LSM dan swasta.

Studi ini menjadikan arena pengelolaan bencana di kawasan lereng Gunung Kelud sebagai titik pijak dalam memahami aktor-aktor yang berperan dalam pengelolaan bencana pasca erupsi tahun 2014. Ketika relasi kuasa beroperasi dalam hubungan-hubungan sosial antar aktor, akan ada pertarungan dan pergumulan antar pelaku (aktor) untuk meraih keunggulan. Menurut Bourdieu (1977), dalam arena sosial yang terdiri dari banyak pelaku (aktor), dengan segala habitus yang dimilikinya, akan terdapat perjuangan secara kontinu untuk saling unggul atau sekedar bertahan. Untuk unggul dan bertahan tersebut mereka berstrategi atau melakukan kiat-kiat dengan menggunakan sumber daya (modal) yang dimilikinya. Selain itu karena setiap orang berada dalam kelompok tertentu, setiap individu hakikatnya berada dalam ragam jaringan kuasa, baik kelompok masyarakat lokal, pemerintah, LSM dan swasta, masing-masing memiliki jaringannya sendiri yang sekaligus menjadi modal dalam berelasi.

Konsep tata kelola (governance) diadopsi untuk memahami realitas yang kompleks dalam kebencanaan. Bencana dalam konteks kekiniian bersifat multidimensional, melibatkan mutistakeholder dan multi-aktor. Sehingga pengelolaan bencana yang hanya menempatkan pemerintah sebagai aktor tunggal jelas tidak relevan lagi di tengah semakin kuatnya semangat dan komitmen masyarakat global untuk membangun masyarakat yang tangguh dalam menghadapi bencana. Apalagi untuk konteks negara berkembang seperti Indonesia di mana aktor formal belum sepenuhnya memiliki kapasitas yang dibutuhkan, sementara terdapat potensi dan energy sosial dari aktor non 
pemerintah (civil society) seperti masyarakat lokal, NGO/LSM yang ada di berbagai wilayah yang rentan bencana. Dengan konsep good governance, pengelolaan bencana tidak lagi bertumpu pada peran tunggal dari pemerintah namun bersifat multi-aktor dan membuka ruang bagi keterlibatan masyarakat lokal, NGO/LSM serta swasta dengan bersandar pada prinsip pengelolaan yang bersifat adil, jujur, setara, efisien, transparan dan akuntabilitas (Aminah, Siti, 2016:.266-267).

\section{DESKRIPSI KOMUNITAS DI KAWASAN RAWAN BENCANA GUNUNG KELUD}

Komunitas di kawasan Gunung Kelud pada dasarnya merupakan realitas kehidupan sosial yang kompleks. Komunitas di kawasan lereng Kelud sebagai entitas sosial, tidak terlepas dari kompleksitas yang dihadapi terkait kerentanan yang dialami dalam kehidupan sehari-hari. Komunitas di kawasan Gunung Kelud, sebagian besar merupakan petani. Sebagai petani, kerentanannya tidak saja karena faktor tempat tinggal di mana secara geografis masuk dalam wilayah rawan bencana erupsi gunung Kelud sehingga komunitas yang hidup di lereng Kelud harus menghadapi berbagai bentuk ancaman dan risiko akibat erupsi dan dampak lanjutan seperti longsor dan banjir lahar.

Erupsi Kelud 13 Februari 2014 yang lalu pada dasarnya merupakan peristiwa berulang yang dapat dilacak dalam sejarah kegunungberapian di Jawa, namun bagi sebagian masyarakat masih dianggap sebagai pengalaman baru yang berimplikasi pada respon dan kesiapsiagaan saat erupsi terjadi. 'Kegagapan' dari berbagai pihak saat proses 'tanggap darurat', proses evakuasi dan di pengungsian masih terlihat. Erupsi Kelud 2014 memang berdampak luas tidak hanya dirasakan masyarakat yang tinggal dikawasan Kelud seperti Kediri, Blitar Malang dan Tulungagung, namun juga dirasakan sebagian besar masyarakat di pulau Jawa. Berdasarkan data BNPB yang dilansir pemerintah propinsi Jawa Timur (Kompas, 20 Februari 2014) Jumlah pengungsi mencapai 87.629 orang. Tercatat 7 korban meninggal dunia karena faktor usia di barak pengungsian, termasuk relawan mahasiswa yang tersengat listrik pada saat mengevakuasi pengungsi di desa Pandansari Kecamatan Ngantang kabupaten Malang. Berdasarkan pendataan Pusat Data Informasi dan Humas PNPB dampak langsung dari erupsi Gunung Kelud menimbulkan kerugian Rp.392,66 miliar. Sedangkan kerusakan bangunan meliputi rumah 3.782 unit, kantor bangunan pemerintah 20 unit, prasarana pendidikan 25 unit, prasarana kesehatan 9 unit, tempat ibadah 36 unit,dan kerusakan sarana air bersih 8.095m3. Kerusakan lahan pertanian terdapat lahan pertanian sawah seluas 5.146 ha, lahan pertanian kebun 1.792 ha, dan tanaman buahn 260.060 pohon, termasuk peternak sapi perah terdapat 25.290 ekor terdampak (Kompas, 9/3 2014).

Sebagai salah satu gunung berapi aktif di dunia dengan karakteristik letusan yang eksplosif, kedahsyatan dampak erupsi Kelud juga terekam sejarah sejak jaman Kolonial Belanda yaitu pada tahun 1919, dengan korban meninggal mencapai 5.115 orang. Lahirnya badan penanggulangan bencana yang sekarang Biro Mitigasi dan Vulkanologi sekarang BVMKG tidak terlepas dari upaya pemerintah Belanda pada waktu itu untuk mengurusi kegunungmerapian, mitigasi dan dampak yang ditimbulkan akibat erupsi gunung berapi. Dalam dua dekade, Kelud telah mengalami erupsi pada tahun 1990, 2007 dan 2014.

Tabel 1. Sejarah Letusan gunung Kelud

\begin{tabular}{|c|c|c|c|}
\hline No & Tahun & $\begin{array}{c}\text { Luncuran awan } \\
\text { panas }(\mathbf{k m})\end{array}$ & Korban jiwa \\
\hline 1 & 1901 & 37,5 & - \\
2 & 1919 & 6,5 & 5.115 \\
3 & 1951 & 31 & 7 \\
4 & 1966 & 5 & 210 \\
5 & 1990 & - & 34 \\
6 & 2007 & - & - \\
7 & 2014 & 3 & 6 \\
\hline
\end{tabular}

Sumber: Data diolah dari BPBD Kabupaten Kediri, 2017 
Terkait erupsi kelud 2014. Di wilayah kabupaten Kediri, terdapat 4 kecamatan terdampak erupsi Kelud 2014 yang meliputi kecamatan Puncu, Kepung, Ngancar, dan Plosoklaten. Empat wilayah ini merupakan daerah terdampak langsung, namun besaran dampak yang dirasakan masyarakat berbeda-beda. Kecamatan yang mengalami kerusakan paling parah akibat erupsi gunung Kelud yaitu Puncu dengan jenis kerusakan bagunan kategori berat mencapai 8.622 dan kategori sedang mencapai 5.466 unit. Dampak kerusakan rumah terparah sebagian besar dialami warga desa Besowo mencapai 1.842 unit. Kerusakan rumah kategori berat juga dialami warga kecamatan Puncu terutama warga desa Puncu dan Asmorobangun. Selain itu kerusakan rumah kategori berat juga dialami warga di kecamatan Kepung terutama di desa Kebon Rejo dan desa Kampung Baru. Sementara kerusakan sedang terjadi hampir di semua wilayah terdampak di empat kecamatan yaitu kecamatan Puncu, Kepung, Ngancar dan Plosoklaten sebagaimana yang terlihat dalam tabel 2.

Tabel 2 Data Kerusakan Rumah Akibat Erupsi Gunung Kelud 2014 Di Kabupaten Kediri

\begin{tabular}{|c|c|c|c|c|}
\hline \multirow[t]{2}{*}{ No } & \multirow[t]{2}{*}{ Kecamatan } & \multirow[t]{2}{*}{ Desa } & \multicolumn{2}{|c|}{ Ketegori kerusakan } \\
\hline & & & Berat & Sedang \\
\hline \multirow[t]{3}{*}{1} & Puncu & Puncu & 1.732 & 433 \\
\hline & & Asmorobangun & 1.756 & 504 \\
\hline & & Satak & 756 & 189 \\
\hline \multirow[t]{2}{*}{2} & Kepung & Kebon Rejo & 1.120 & 172 \\
\hline & & Kampung Baru & 1.168 & 318 \\
\hline \multirow[t]{11}{*}{3} & Ngancar & Besowo & 1.842 & 460 \\
\hline & & Mergourip & 9 & 348 \\
\hline & & Pandantoyo & 15 & 354 \\
\hline & & Jagul & 16 & 221 \\
\hline & & Ngancar & 19 & 312 \\
\hline & & Manggis & 15 & 354 \\
\hline & & Kunjang & 13 & 342 \\
\hline & & Bedali & 14 & 412 \\
\hline & & Babadan & 11 & 331 \\
\hline & & Sugihwaras & 14 & 342 \\
\hline & & Sempu & 17 & 334 \\
\hline \multirow[t]{4}{*}{4} & Plosoklaten & Wonorejo Trisulo & 30 & - \\
\hline & & Sepawon 60 & 60 & - \\
\hline & & Jarak 15 & 15 & - \\
\hline & JuI & & 8.622 & 5.466 \\
\hline
\end{tabular}

Sumber: BPBD Kabupaten Kediri Tahun 2017.

Besarnya dampak kerugian yang diderita oleh warga di lokasi terdampak erupsi Kelud membawa dampak bagi korbannya, terutama dampak ekonomi dan dampak psikologis. Kerugian akibat kehilangan rumah, kehilangan hasil panen yang sudah di depan mata, serta ketidak jelasan akan masa depan secara langsung maupun tidak langsung akan mempengaruhi kehidupan masyarakat. Perubahan yang terjadi secara drastis juga dapat berimplikasi pada kondisi psikologis korban. Untuk bisa bertahan dalam menghadapi situasi seperti itu jelas membutuhkan mekanisme adaptasi untuk mampu mengelola kondisi buruk tersebut agar tidak mempengaruhi kehidupan dan penghidupannya di masa datang atau menurut Tugade dan Federikson (2004) dikenal dengan istilah 'resiliensi'.

Fakta lain yang tidak dapat dipungkiri di balik erupsi gunung Kelud tahun 2014 adalah masih adanya anggapan bahwa erupsi yang terjadi merupakan pengalaman baru bagi sebagian masyarakat, sesuatu yang belum pernah terjadi sebelumnya. Sebagaimana yang diungkap Irwan Abdullah (2012:46).) bahwa meski sudah berulangkali terjadi, bencana masih sering dianggap sebagai 
pengalaman baru, sesuatu yang belum pernah terjadi sebelumnya, sehingga belum menjadi pengetahuan dan pengalaman kolektif. Akibatnya bencana belum terintegrasikan dalam kehidupan dan kebijakan sosial (Indiyanto \& Kuswanjoyo, ed, 2012).

Bagi masyarakat di kawasan Kediri dan Blitar, sebagian warganya memperoleh banyak pelajaran dari pengalaman erupsi Kelud yang terjadi tahun 1966 dan 1990. Lontaran material vulkanik saat erupsi dan dampak lanjutan banjir lahar hujan yang pernah dialami warga Blitar dan Kediri. Ditambah masih hidupnya 'legenda' atau mitos 'Lembu Syuro' dengan sumpahnya "Blitar dadi latar, Kediri dadi kali, Tulungagung dadi kedung" menjadi memori kolektif (ingatan sosial) sehingga warga cenderung lebih siap dan siaga menghadapi ancaman aktivitas gunung Kelud termasuk melakukan proses evakuasi secara mandiri.

Hal yang berbeda dengan warga di kabupaten Malang seperti kecamatan Ngantang dan Kasembon. Bagi sebagian besar warga Malang, erupsi Kelud 2014 dan dampak yang dialami dianggap sebagai pengalaman baru. Terbatasnya referensi tentang dampak erupsi Kelud bagi warga di kawasan Malang dapat memperparah kerentanan bagi sebagian warga. Dengan melacak sejarah kedahsyatan erupsi Kelud seperti yang pernah terjadi tahun 1919 dengan korban meninggal mencapai 5.478 jiwa dipandang penting untuk mengubah cara pandang tentang bencana. Selain itu, pola pengelolaan bencana di kawasan gunung berapi yang didasarkan pada karakterisktik dari gunung berapi itu sendiri dan kondisi sosial budaya masyarakat lokal, koordinasi, keterlibatan masyarakat lokal, peran dan tengggung jawab berbagai pihak menjadi keniscayaan.

Berdasarkan pengalaman itulah Jangkar Kelud sebagai organisasi nirlaba (Non Goverment Organization/NGO) yang lahir dari komunitas lokal sejak tahun 2008 menginisiasi pengembangan Desa bersaudara (Sister Village) di kawasan rawan bencana Gunung Kelud sebagai alternative model pengelolaan bencana berbasis kapasitas lokal dengan lebih berorientasi pada penanganan pengungsi. Selanjutnya program sister village difasilitasi pemerintah kabupaten Kediri melalui BPBD ddengan dukungan anggaran dari APBD. Untuk pelaksanaan di tingkat desa, program sister village dikembangkan pemerintahan desa Sempu kecamatan Ngancar Kabuapaten Kediri sebagai desa pengungsi dan desa Pojok dan Segaran kecamatan Semenan sebagai desa penyangga. Untuk memahami bagaimana program Desa bersauadara (sister village) di KRB Gunung Kelud, berbagai temuan lapangan terkait pengelolaan bencana disajikan dalam tulisan berikut ini.

\section{PERAN PEMANGKU KEPENTINGAN DALAM PENGELOLAAN BENCANA DI KRB KELUD KABUPATEN KEDIRI}

Pengelolaan bencana atau manajemen bencana sebagaimana diatur dalam UU No 24 tahun 2007 dan PP No 21 tahun 2008 mencakup semua aspek perencanaan untuk merespons bencana, termasuk kegiatan sebelum bencana dan setelah bencana yang mungkin juga merujuk pada managemen risiko dan konsekuensi bencana dari Sgaluf (dalam Kusumasari, 2014:19). Menurut Kelly (1995) managemen bencana meliputi semua perencanaan, pengorganisasian, dan mobilisasi sumber daya yang dibutuhkan untuk menangani semua fase bencana sebagai peristiwa alam yang unik. Selanjutnya Quarantelli dan Coppola (2014:21) menyatakan bahwa dalam siklus managemen bencana ada empat aktivitas yang sangat penting dilakukan yaitu kegiatan mitigasi dan kesiapsiagaan dalam tahap prediksi, kegiatan respons dalam tahap peringatan dan bantuan darurat, serta kegiatan pemulihan dalam tahap rehabilitasi dan rekonstruksi. Dalam manajemen bencana alam dan manajemen bencana modern terdapat empat aktivitas penting yang dilakukan termasuk yang diatur dalam UU no 24 tahun 2007 dan PP no 21 tahun 2008 dalam penanggulangan bencana di Indonesia yaitu; mitigasi, kesiapsiagaan, respons dan pemulihan (Kusumasari, 2014)

Selanjutnya tulisan beikut membahas pengelolaan bencana di KRB Gunung Kelud dalam melakukan mitigasi dan membangun kesiapsiagaan masyarakat. Berbagai pemangku kepentingan terlibat dalam pengelolaan bencana antara lain; pemerintah daerah, BPBD kabupaten Kediri, pemerintahan desa dan aparaturnya, Komunitas Jangkar Kelud, tokoh masyarakat, relawan dan 
warga yang tinggal di KRB Kelud. Berikut ini temuan lapangan terkait para pemangku kepentingan yang terlibat dalam mitigasi dan kesipasiagaan masyarakat dalam menghadapi ancaman erupsi Kelud di Kabupaten Kediri. Berikut ini,

\section{BPBD KABUPATEN KEDIRI}

Pemerintah sebagai pihak yang mempunyai peranan terpenting dalam penanggulangan bencana, harus memiliki kemampuan koordinasi dengan instansi-instansi pemerintah lainnya yang memiliki kewenangan dalam penanggulangan bencana. Dalam hal ini Badan Penanggulangan Bencana Daerah (BPBD) Kabupaten Kediri sebagai pemegang komando dalam penanggulangan bencana di Kabupaten Kediri. Dalam melakukan koordinasi, BPBD Kabupaten Kediri bekerjasama dengan SKPD lainnya.

Pada saat Gunung Kelud erupsi tahun 2014, penanggulangan bencana dilaksanakan satuan koordinasi pelaksana penanggulangan bencana (Satkorlak) yang dibentuk Pemerintah Kabupaten Kediri. BPBD kabupaten Kediri baru dibentuk tahun 2015 melalui Perda No 2 Tahun 2015 tentang Tata Laksana Organisasi Penanggulangan Bencana Daerah. Selanjutnya dalam melaksanakan tugas dan fungsinya BPBD Kabupaten Kediri membuat jaringan untuk mengtahui permasalahan dalam melakukan mitigasi bencana. Dalam hal ini BPBD Kabupaten Kediri berkerjasama dengan NGO, masyarakat bisnis dan komunitas atau paguyupan yang ada di masayrakat. Salah satu yang dilakukan BPBD Kabupaten Kediri yaitu membentuk Forum Komunikasi Pengurangan Risiko Bencana (FKPRB) Kabupaten Kediri. Hal itu bertujuan untuk memudahkan melakukan sosialisasi terkait mitigasi bencana erupsi Kelud kepada masyarakat. Hal ini sebagaiman disampaikan oleh Staf Pencegahan dan Kesiapsiagaan (Bapak Dadik Raharja) BPBD Kabupaten Kediri bahwa:

"Setelah BPBD Kabupaten Kediri terbentuk, untuk menjalankan tugas dan fungsi intitusi tidak dapat berjalan sendiri, apalagi sebagai institusi baru di lingkungkan pemerintahan kabupaten Kediri. Salah satunya membentuk Forum Komunikasi Komunitas Pengurangan Risiko Bencana(FKPRB) di kabupaten Kediri yang beranggotakan relawan yang bergerak dalam pengurangan risiko bencana di Kabupaten Kediri. Dengan membangun komunikasi, jaringan, dan kerjasama dapat dijadikan salah satu pendekatan penyampaian informasi dan program mitigasi bencana yang nantinya bisa langsung di sampaikan kepada masyarakat di lokasi relawan berada di samping masih ada upaya pendekatan yang lain kepada masyarakat. Mitigasi dilakukan melalui sosialisasi, pembentukan desa tangguh bencana dan sekolah siaga bencana dan yang saat ini dijalankan adalah penegmbangan program sister village (desa bersaudara).." (Sumber: wawancara tanggal 9 April 2018)

BPBD Kabupaten Kediri secara regular harus membangun jejaring dan kerja sama dengan para pemangku kepentingan seperti jaringan NGO Jangkar Kelud yaitu UNDP, FAO dan masyarakat lokal yang tinggal di KRB Gunung Kelud. Dalam kegiatan mitigasi, masyarakat yang terlibat terlebih dahulu harus diberikan sosialisasi dan apabila telah timbul kesadaran kemudian diberikan simulasi. Strategi BPDB Kabupaten Kediri dalam meningkatkan pengetahuan dan keterampilan masyarakat untuk mengikuti sosialisasi, selanjutnya diberikan materi simulasi. Setelah simulasi diberikan dilaksanakan lokalatih. Mitigasi bencana dilakukan dalam bentuk sosialisasi, pembentukan desa tangguh bencana (destana), sister village dan sekolah siaga bencana. Dalam hal meningkatkan respon masyarakat dalam mitigasi bencana, menurut Bapak Dian Dwi Permana,S,SPT (BPBD Kabupaten Kediri) bahwa:

"BPBD Kediri melakukan kegiatan - kegiatan mitigasi non-fisik, seperti sosialiasi, peningkatan skill dalam penanggulangan bencana, memfasilitasi komunitas peduli bencana, mengadakan sekolah siaga bencana. Sekolah siaga bencana disesuaikan dengan daerah yang rawan bencana yang ditunjuk oleh pemerintah dengan melakukan pelatihan-pelatihan agar sekolah- 
sekolah dapat tertarik melaksanakan kegiatan-kegiatan rawan bencana." (Wawancara 17 Juli 2018 pukul $10.00 \mathrm{Wib})$

Dalam melaksanakan kegiatan mitigasi bencana, BPBD Kabupaten Kediri berkoordinasi dengan aparat setempat, baik di tingkat kecamatan dan desa serta para tokoh masyarakat sehingga dalam melakukan program mitigasi bencana diantara satu lokasi dengan lokasi yang lainnya dilaksanakan sesuai dengan karakter masing-masing tempat. Aparat pemerintah berkewajiban untuk menyiapkan sumber daya dalam kegiatan mitigasi, namun apabila masyarakat mempunyai sumber daya tersendiri maka dapat dikolaborasikan.

\section{KOMUNITAS JANGKAR KELUD}

Selain BPBD, implementasi dalam program Komunitas Jangkar Kelud terlibat dalam menjalankan program - program ketika di lapangan dan berkoordinasi pada saat penangan bencana. Sebagaimana dijelaskan oleh Mbah Darmo (Nama Asli; Catur Sudarmanto) Koordinator Komunitas Jangkar Kelud sebagai berikut.

"Pertama, Komunitas Jangkar Kelud memperkuat institusi, mekanisme, dan kapasitas dalam program mitigasi bencana dengan melakukan pelatihan - pelatihan perkuatan penanggulangan bencana. Kedua menggunakan momentum Kelud untuk mengadvokasi kebijakan pemerintah daerah di Kediri, Blitar dan Malang terhadap pentingnya lembaga yang permanen, bukan lembaga yang responsible. Ketiga melakukan rekruitmen yang berawal dari mantan - mantan relawan dan melakukan pelatihan yang mengubah mindset bahwa bencana tidak hanya sekedar tanggap darurat tetapi sampai urusan mitigasi dan rehabilitasi." (Wawancara Tanggal 17 September 2018 Pukul $13.00 \mathrm{Wib}$ )

Dalam manajemen sumber daya, Komunitas Jangkar Kelud melakukan koordinasi dengan masyarakat apa yang dibutuhkan masyarakat dalam kebutuhan di desa tersebut. Berdasarkan analisis kebutuhan masyarakat itulah kemudian Jangkar Kelud mendesign konsep proposal dan mencari pihak ketiga yang bisa membantu dalam pengadaan tersebut dan kemudian secara teknik masyarakat bergotong royong untuk menggunakan bantuan - bantuan tersebut. Jangkar Kelud menjaga filosofi sebagai fasilitator yang mampu mendayagunakan kapasitas masyarakat sendiri, dengan jargon "Ora penting kondang sing penting tandang"

Dalam pengelolaan pasca bencana, Jangkar Kelud bersama BPBD Kabupaten Kediri melakukan program sistem pemulihan ekonomi korban erupsi gunung Kelud bersama Pemkab Kediri, UNDP dan FAO. Program ini dilatarbelakangi oleh banyaknya korban secara materi akibat erupsi Kelud, salah satunya kerusakan bangunan berdampak juga kerusakan pada bidang pertanian yang berdampak pada hancurnya perekonomian masyarakat misalnya di wilayah Sempu, Besowo, Kepung (Kediri), Nglegok-Blitar dan Pandansari-Ngantang-Malang. Untuk itu dalam kegiatan pemulihan ini Jangkar Kelud bekerja sama dengan Pemerintah Daerah Kabupaten, UNDP dan FAO. Secara umum kegiatan ini akan emetakan persoalan persoalan perekonomian masyarakat dan merumuskan perencanaan pemmulihan perekonomian masyarakat tersebut.

Dalam melakukan pendampingan dalam penanganan bencana untuk masyarakat di KRB menyatakan beberapa kendala yang dihadapi. Pertama, Sebagian masyarakat belum menyadari, belum memahami akan risiko bencana di KRB gunung berapi; Kedua, masyarakat sudah merasa nyaman dan aman tinggal dilokasi awal. Mereka meanggap apabila akan terjadi Erupsi Kelud pasti dapat diketahui tanda-tandanya terlebih dahulu. Ketika, alasan ekonomi. Masyarakat menganggap apabila tinggal di barak pengungsian itu tidak efisien, karena mereka harus bolak-balik dari pengungsian ke tempat yang menjadi mata pencahariaan mereka. Hal yang sama juga disampaikan Bapak Dadik (BPBD Kabupaten Kediri) yang menyatakan: 
"Masyarakat yang tinggal di KRB Kelud, baik KRB I, II, dan III sebagaian besar sudah berlangsung lama dan turun-menurut. Sehingga bukan opsi yang rasional jika menghimbau mereka untuk meninggalkan atau pindah dari tempat tinggal yang sudah menjadi bagian dari sejarah kehidupannya. Daerah di sekitar Kelud sudah menjadi bagian hidup, hak milik mereka sendiri dan bisa digunakan untuk kegiatan perekonomian baik itu peternakan, perkebunan maupun kenyataan mereka juga, di sana juga untuk wisata juga ini yang pertama. Kedua mereka memang merasa aman tinggal di sana merasa tidak terancam apapun karena dia tahu Kelud itu berkala dan bisa dilihat tanda tandanya dan mereka siap kalau ada tandatandanya mau meletus mereka siap kapanpun untuk mengungsi gitu dan kebanyak mereka punya tempat dimana harus mengungsi gitu. Sehingga kalo saya ya perlu dikembangkan kearifan 'sitik edang' artinya bahwa Kelud sudah memberikan keberkahan yang luar biasa bagi masyarakat sekitar, sehingga masyarakat perlu juga memberi ruang dan waktu sejenak bagi Kelud untuk melakukan aktifitas alam atau yang disebut erupsi...."

Dalam menjalankan tugas dan fungsi institusi yang relatif baru dalam penanggulangan bencana di daerah kabupaten kediri, pemerintah dalam konteks ini Badan penanggulangan Bencana (BPBD) Kabupaten Kediri merasa sangat beruntung ada NGO Komunitas Jangkar Kelud yang banyak membantu dalam penguatan kelembagaan dan berjejaring dengan berbagai komunitas di KRB, komunitas penanggulangan bencana di tingkat nasional seperti Kapalla,UPN Yogyakarya, PujionoCenter dan berjejaring dengan NGO internasional seperti UNDP dan FAO.

"Terus terang kami sangat terbantu dengan Mbah Darmo-Jangkar Kelud. Kapasitas dan pengalaman beliau dalam penanggulangan bencana sejak tahun 2008, penguatan kelembagaaan dan kapasitas masyarakat di kawasan rawan bencana gunung Kelud sangat luar biasa, rekam jejak dan daya jelajahnya sudah go internasional. Jaringan yang Mbah Darmo bangun mulai dengan UNDP, FAO, UPN Yogyakarta, dan NGO-NGO di tingkat nasional yang berkecimpung dalam penanggulangan bencana sangat membantu kami dalam mengembangkan BPBD sebagai institusi baru di lingkungan Pemkab Kediri. Makanya kami melakukan kerjasama kolaboratif secara berkelanjutan dengan Jangkar Kelud dan masyarakat di KRB gunung Kelud yang berada dalam wilayah dampingannya. (Wawancara mendalam dengan Pak Dadik (Sie Pencegahan dan Kesiapsiagaan BPBD-Kab Kediri Tanggal 29 April 2018 di desa Besowo dalam kegiatan Pengembangan Sister Village di Kawasan Rawan Bencana Gunung Kelud Kabupaten Kediri).

Gambar 1. Kegiatan Koordinasi BPBD Kabupaten Kediri dan UNDP

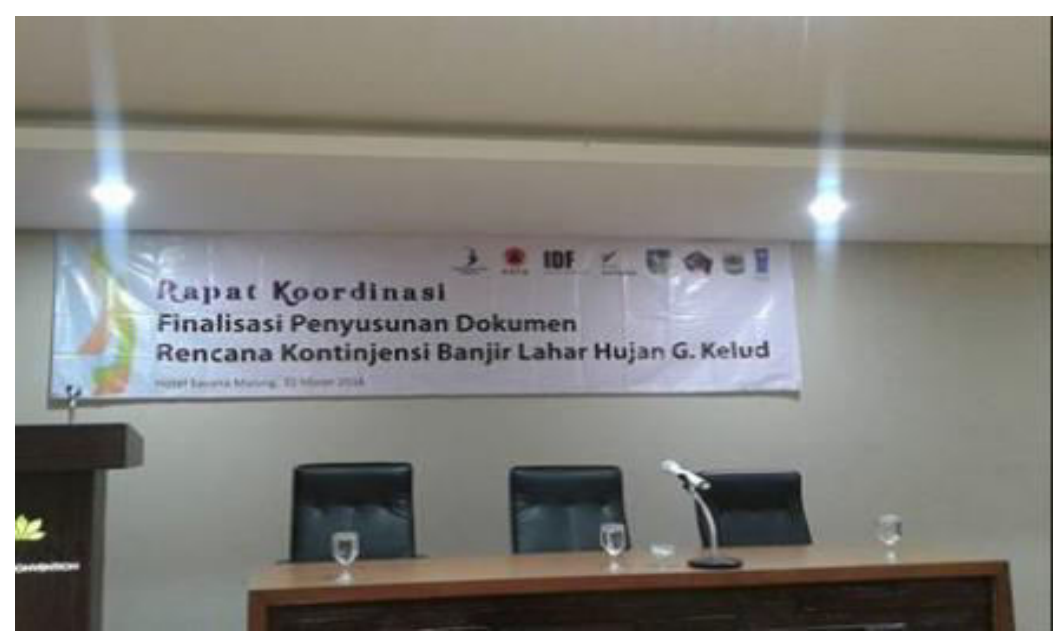


Keterangan: Rapat kordinasi Strategi keberlanjutan Program Kerjasama UNDP dan BPBD Kabupaten Kediri di bertempat di Hotel Grand Surya Kota Kediri, acara yang diselenggarakan pada tanggal 28 Maret 2016. Sumber: BPBD Kabupaten Kediri.

Demikian juga dalam upaya melakukan pendekatan kepada masyarakat dalam proses sosialisasi program, penyadaran, pengembangan program sister village, membangun kesiapsigaan dan ketangguhan masyarakatdalam menghadapi bencana, BPBD belajar banyak dan membangun kerjasama secara kolaboratif dengan Jangkar Kelud dan komunitas-komunitas lokal yang berada dalam jaringan Jangkar Kelud.

\section{Masyarakat}

Selain Jangkar Kelud pemangku kepentingan yang tak kalah penting adalah masayarakat lokal yang tinggal di KRB Kelud. Pada saat mitigasi bencana seluruh elemen masyarakat dilibatkan mulai dari Pemerintah daerah sampai masyarakat biasa. Pemerintah daerah membuat unit pelaksana yang terdiri dari badan vulkanologi, BPBD, kecamatan, aparatur desa, relawan, dan tokoh masyarakat. Tugasnya adalah untuk melakukan sosialisasi dan peringatan kondisi Gunung Kelud, menyiapkan barak pengungsian, dapur umum, menyediakan mobil evakuasi, dan hal-hal lain yang bersangkutan dengan mitigasi bencana.

Untuk saat ini khususnya di Desa Sempu Kecamatan Ngancar kabupaten Kediri sudah menjadi KSB (Kampung Siaga Bencana) dan saat ini sedang mengembangkan ke arah Desa Tangguh Bencana (Destana) di mana saat ini menjadiagenda program BPBD Kabupaten Kediri, tugasnya tidak jauh berbeda dengan unit pelaksana yang dibuat oleh pemerintah daerah. Perbedaanya adalah KSB berbasis pemberdayaan masyarakat yang terdiri dari kepala dusun, RT/RW, tokoh masyarakat, karang taruna, PKK, dan masyarakat desa Sempu.

Dalam pemanfaatan sumber daya dari berbagai elemen yang terlibat pada saat mitigasi bencana yakni pemerintah daerah, menyiapkan segala kebutuhan sarana prasarana dan logistik pada saat peringatan sampai dengan di lokasi pengungsian dan dibantu oleh para relawan dan pihak swasta. Misalnya, pemerintah daerah menyiapkan dana relokasi, HT untuk mempermudah akses Informasi, mobil evakuasi, dan sebagainya. Kemudian, relawan menyiapkan mobil evakuasi dan siap sedia di lokasi untuk memberikan informasi kepada masyarakat serta membantu evakuasi. Dan pihak swasta membantu dana logistik. Menurut Bapak Eko Suroso, SPd (Kepala Desa Sempu kecamatan Ngancar kabupaten Kediri) menjelaskan bahwa:

"Pemilihan pendekatan berbasis komunitas dilakukan agar masyarakat ikut berpartisipasi dalam mitigasi bencana karena hal tersebut akan memudahkan proses mitigasi, relokasi, sampai dengan pasca erupsi terjadi. Misalnya dalam proses mitigasi, masyarakat dalam hal ini kepala dusun, tokoh masyarakat, dan juga pemuda desa sering diajak diskusi agar infomasi dapat terus tersampaikan kepada masyarakat lainnya. Selain untuk menyampaikan informasi, masyarakat juga diajak berdiskusi mengenai jalur evakuasi yang nantinya akan digunakan pada saat relokasi" (Wawancara Tanggal 19 Juli 2018 Pukul 15.30 WIB).

Untuk merespon ide dan pengalaman warga atau korban bencana erupsi Gunung Kelud dilakukan dengan cara musyawarah dengan warga atau mengumpulkan tokoh masyarakat yang ada disana. Kemudian setelah itu diimplementasikan pada program mitigasi dan pemulihan bencana. Untuk mengatasi keragaman kebutuhan, praktek, kebiasaan, adat istiadat, keyakinan, budaya masyarakat setempat dalam program mitigasi bencana dilakukan dengan cara mengumpulkan warga untuk berdiskusi atau mengundang tokoh-tokoh masyarakat.

Sementara itu, menurut Bapak Eko Suroso, SPd menyatakan bahwa :

"Dalam hal mitigasi bencana, pemerintah daerah, NGO dan masyarakat memanfaatkan sumber daya yang ada di dalam masyarakat dengan cara melibatkan langsung dalam 
perencanaan dan pelaksanaan program. Misalnya program Sister Vilage, yang dilakukan oleh pemerintah daerah, NGO dan masyarakat dalam memperkuat soft skill, ketrampilan kolaborasi, kerjasama tim. Untuk saat ini sumber anggaran kegiatan berasal dari dana pemerintahan desa yang digunakan untuk penanganan bencana seperti membeli 6 HT yang dipakai relawan desa yang terlibat dalam pengelolaan bencana di desa Sempu, KRB 2 Gunung Kelud. HT diberikan untuk setiap dusun, karena HT ini lah yang sangat berfungsi jika Kelud erupsi. Seperti yang terjadi tahun 2014 lalu, komunikasi yang paling lancar ya dengan HT.. (Wawancara Tanggal 19 Juli 2018 Pukul 15.30 WIB).

Erupsi Gunung Kelud yang terjadi 13 Pebruari 2014, mengeluarkan abu vulkanik yang menyebar luas dikabupaten terdampak di propinsi Jawa Timur. Bahkan abu menimbulkan bandara di jatim, Jateng dan Jogjakarta ditutup untuk beberapa hari. Tercatat 201.228 Orang mengungsi akibat letusanya atau sekitar 58.341 rumah tangga di 35 desa dan 10 kecamatan yang berada lingkar Kelud. Dampak yang sebegitu luas menyebabkan kerusakan yang masif memberikan respon positif masyarakat untuk segera berbenah. kelumpuhan ekonomi segera tertangani, sehingga tidak begitu lama perekonian masyarakat pulih.

UNDP sebagai lembaga internasional melalui kerangka kerjasama BNPB dan Kementrian Bappenas merasa perlu segera melakukan tindakan rehabilitasi dan rekonstruksi melalui penguatan pemerintahan, dalam hal ini BPBD dan penguatan Kapasitas masyarakat dalam menanggulangi bencana. melalui Lokalatih Pengurangan risiko bencana atas ancaman Banjir lahar Hujan kali lahar yang berhulu di Gunung Kelud, menyediakan data kependudukan sebagai sistem informasi kebencanaan melalui program Sistem Informasi desa dan Sistem Informasi Kebencanaan. Menurut sekda Kabupaten Kediri Drs. Supoyo, SH menyatakan bahwa kerjasama dengan UNDP sangat membantu masyarakat dan pemerintah dalam membangun ketangguhan dalam menghadapi bencana akibat Gunung Kelud, baik ancaman primer maupun sekundernya. Kerjasama yang terjalindiharapkan menjadi katalisator prespektif pemerintah dalam membangun ketangguhan kabupaten Kediri.

\section{Peran Desa dalam Penanggulangan Bencana: Temuan Di Desa Sempu Kecamatan Ngancar Kabupaten Kediri}

Pengetahuan dan pemahaman bahwa secara geografis Indonesia merupakan salah satu negara yang memiliki potensi kerawanan tinggi terkait bencana alam, maka penting menjadi pengetahuan kolektif bahwa bencana dapat terjadi kapan saja, di mana saja dan dapat menimpa siapa saja. Dalam arti bahwa di manapun kita berada baik di daerah gunung, sungai, atau bahkan pantai sekalipun bencana bisa saja terjadi dan tanpa memilih milih siapa yang akan menjadi korban dan tak akan pernah janjian kapan bencana itu akan datang.

Desa sebagai ujung tombak pemerintahan menjadi sangat penting dalam usahanya membangun kesiapsiagaan dalam penanggulangan bencana. Aparat pemerintahan desa harus mampu mejadi motor gerakan penanggulangan bencana diwilayahnya, artinya dalam hal ini setiap aparat pemerintahan desa mau tidak mau harus paham dan mengerti apa itu bencana dan bagaimana bersikap jika bencana terjadi untuk menyelamatkan warganya tanpa harus bergantung pada pihak lain. Pemerintah desa menjadi sebuah pihak yang sangat penting dalam usaha penanggulangan bencana, hal ini karena desa selain sebagai ujung tombak pemerintahan juga sebagai sentra pengatur masyarakat secara langsung yang bersentuhan dan berinteraksi di daerah. Setiap desa memliliki kapasitas, dan sumberdaya yang ada di desa untuk memfasilitasi kegiatan penanggulangan bencana. Hal ini sejalan dengan konsep kapasitas dari International Strategic on Disaster Reduction (ISDR), adalah kemampuan masyarakat terkena dampak (bencana) untuk menghadapinya dengan sumber daya yang dimilikinya sendiri. 
Gambar 2 Kegiatan Lokalatih dan Simulasi dari Tim Desa Siaga Bencana

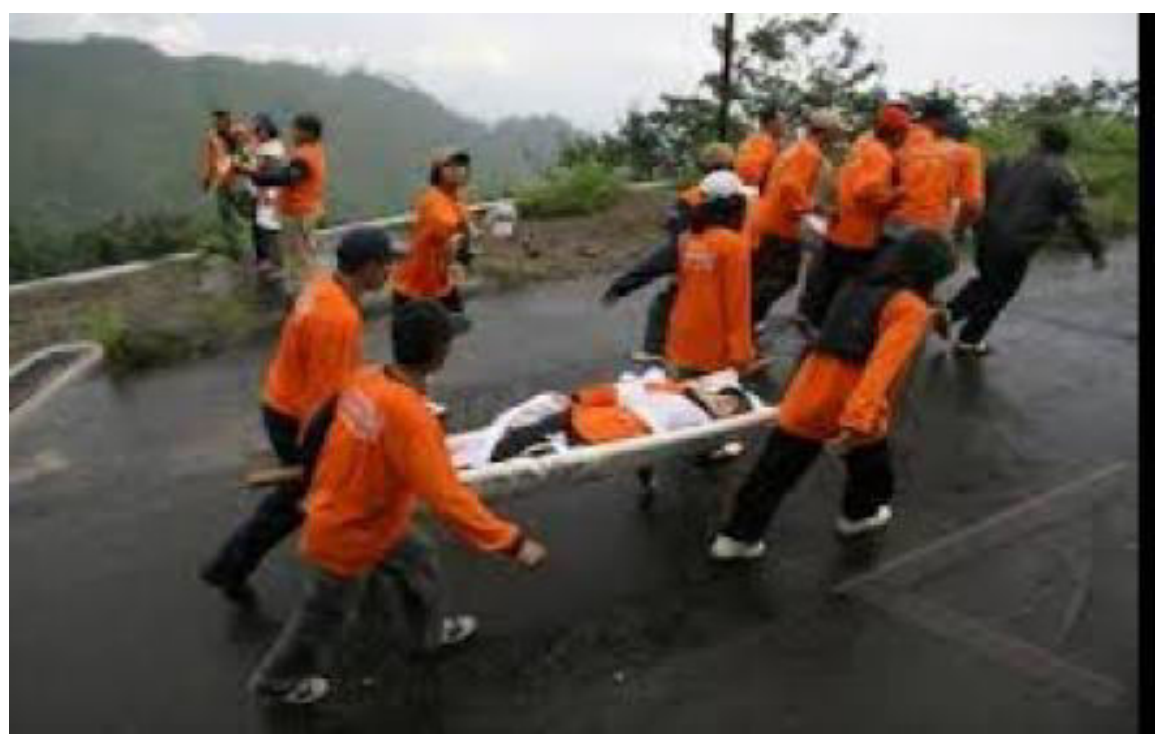

Keterangan: Lokalatih Tim Siaga Bencana Desa Sempu, Gambar diadopsi dari Dokumen Profile Desa Sempu Kecamatan Ngancar, SID 19 April 2018.

Sesuai dengan amanah UU Desa, bahwa peran desa sangat vital dalam penanggulangan bencana. Pelibatan masyarakat dan dunia usaha di lingkup pedesaan juga menjadi ranah positif dalam usaha penanggulangan bencana, namun upaya ini dubutuhkan sebuah aparatur pemerintahan desa yang mampu dan bervisi penanggulangan bencana. Menurut Kades Eko Suroso, SPd, dalam upaya penanggulangan bencana, secara sederhana dapat dilakukan 3 kegiatan yaitu: 1. menjauhkan ancaman bencana dari diri kita 2 . kita menjauh dari ancaman bencana yang ada, atau 3. kita hidup nyaman berdampingan dengan ancaman bencana ketiga upaya tersebut merupakan pilihan yang sewaktu waktu harus kita tentukan guna menyelamatkan masyarakat dari ancaman bencana, dan sekali lagi dibutuhkan aparatur yang bervisi dan paham upaya penanggulangan bencana.

\section{Membangun Kerjasama Antar Desa Dalam Penanggulangan Bencana Di KRB Gunung Kelud Melalui Program Sister Village: Lesson Learnt Di Kecamatan ngancar dan Kepung Kabupaten Kediri}

BPBD kabupaten Kediri bersama Jangkar Kelud mengadopsi program sister village dari BPBD Kabupaten Magelang yang telah berhasil mengembangkan program Desa Bersaudara di KRB Gunung Merapi pasca erupsi 2010. Program sister village merupakan upaya pengurangan risiko bencana dengan menempatkan pengungsi di desa bersaudara yang letaknya di luar Kawasan Rawan Bencana (KRB) Gunung Kelud, sehingga apabila bencana terjadi, masyarakat di KRB Gunung Kelud tidak panik dan bingung karena sudah punya arah dan tujuan yang jelas kemana mereka harus mengungsi.

Program sister village ini menyatukan dua pasang desa atau lebih dalam suatu hubungan yang dilembagakan. Di dalam mempersiapkan penerapan program ini, desa penyangga turut bekerja keras. Hal ini dikarenakan fasilitas dan sarana prasarana pendukung pengungsian berada di desa penyangga, sehingga mereka juga turut berperan dalam penyediaannya. Pemenuhan kebutuhan dasar pengungsian seperti tempat penampungan, tempat logistik, dapur umum, dan tempat MCK 
(mandi, cuci, kakus) harus dipersiapkan dengan baik. Berdasarkan hasil 'sinau bareng', partisipant oberservationt' dalam pelatihan pengembangan sister village di balai desa Sempu-Ngancar, balai Desa Segaran, desa Pojok Wates dan desa Besowo kecamatan Kepung, peneliti menangkap bahwa dalam kenyataannya desa penyangga yang bukan merupakan desa terdampak letusan Gunung Kelud yaitu desa Segaran dan Desa Pojok kecamatan Wates, serta desa Damarwulan kecamatan Kepung tampak antusias dalam mempersiapkan pemenuhan kebutuhan dasar pengungsian tersebut. Antara desa penyangga dengan desa KRB 2 Gunung Kelud juga terlihat kompak dalam mempersiapkan penerapan program sister village ini.

Meskipun dalam proses pelatihan juga diwarnai akti absennya desa Bruumbung dalam kegiatan penegmbangan sister Village, Berdasarkan penggaliaan data di lapangan. Ada beberapa alasan mengapa Desa Brumbung menolak mengikuti program Desa Bersaaudara. Menurut salah satu informan relawan dari desa Besowo menyatakan bahwa desa Brumbung menolak dalam program pengembangan 'sister village' karena warga desa Brumbung sendiri merasa desanya menjadi wilayah potensial terdampak erupsi Kelud sehingga tidak layak dijadikan sebagai desa penyangga untuk para pengungsi dari desa Besowo di mana pada saat erupsi Kelud 2010 termasuk wilayah yang kerusakan masuk kategori tinggi.

Program pengembangan Desa bersaudara atau dalam bahasa Inggris dikenal dengan istilah 'Sister Village' secara sederhana bisa dimaknai sebagai sebuah upaya untuk mempertemukan antara desa yang berada dalam kawasan rawan bencana dengan desa yang berada dalam kawasan aman untuk melakukan sebuah kerjasama dalam penanggulangan bencana. Bisa jadi ini akan menjadi solusi penanganan bencana yang lebih baik, karena disiapkan dengan matang sebelum terjadinya bencana dengan perencanaan dan pembahasan yang mendalam tentang berbagi peran dalam uapaya menyelamatkan warga dari ancaman bencana.

Upaya ini dilakukan sebagai solusi sederhana menyikapi masih semerawutnya penanganan pengungsian di beberapa daerah rawan bencana karena masih berdasar kepada penanganan kedaruratan tanpa didukung kegiatan pra dan pasca bencana. Seberapa hebat kita menyiapkan diri dalam kesiapsiagaan masyarakat di kawasan rawan bencana, namun jika didaerah penerima pengungsi juga tidak kita siapkan maka penangan bencana bisa saja dikatakan gagal. Para pemangku kepentingan baik BPBD, NGO Jangkar Kelud, Pemerintahan Desa, dan masyarakat di kawasan gunung Kelud megakui pentingnya komitmen bersama antar desa dalam lingkup kerjasama sehingga ketimpangan kapasitas dan sumberdaya bisa ditutupi. Hal ini sangat dibutuhkan jika sewaktu waktu terjadi bencana, masyarakat yang berada di daerah rawan bisa segera menyelamatkan diri secara mandiri ke daerah yang aman melalui mekanisme dan aturan yang telah disepakati sebelumnya.

Dalam kondisi aman, sister village dapat dikembangkan secara berkelanjutan dalam upaya kerjasama pembangunan dan penguatan kapasitas serta sumberdaya. Misalnya dibidang ekonomi dan pangan, dimana salah satu desa adalah daerah yang tidak memproduksi padi, bisa bekerjasama dengan daerah produksi dan lumbung padi. Melalui BUMDes dan Kelompok tani, sehingga masyarakat bisa memperoleh beras dengan kualitas baik dengan harga terjangkau karena langsung dari perani produksi. Keuntungan lain yang diperoleh, jika kerjasama ini melibatkan kelompok tani dan BUMDes, maka akan ada banyak perputaran uang yang teradi sehingga kegiatan ekonomi masyarakat bisa meningkat dan dampak lebih luas masyarakat akan semakin tangguh dalam ketahanan pangan dalam menghadapi potensi bencana yang terjadi. 
Gambar 3 Peneliti Sinau Bareng Bersama Jangkar Kelud, BPBD kabupaten Kediri, Relawan dan Masyarakat Dalam Program Sister Village
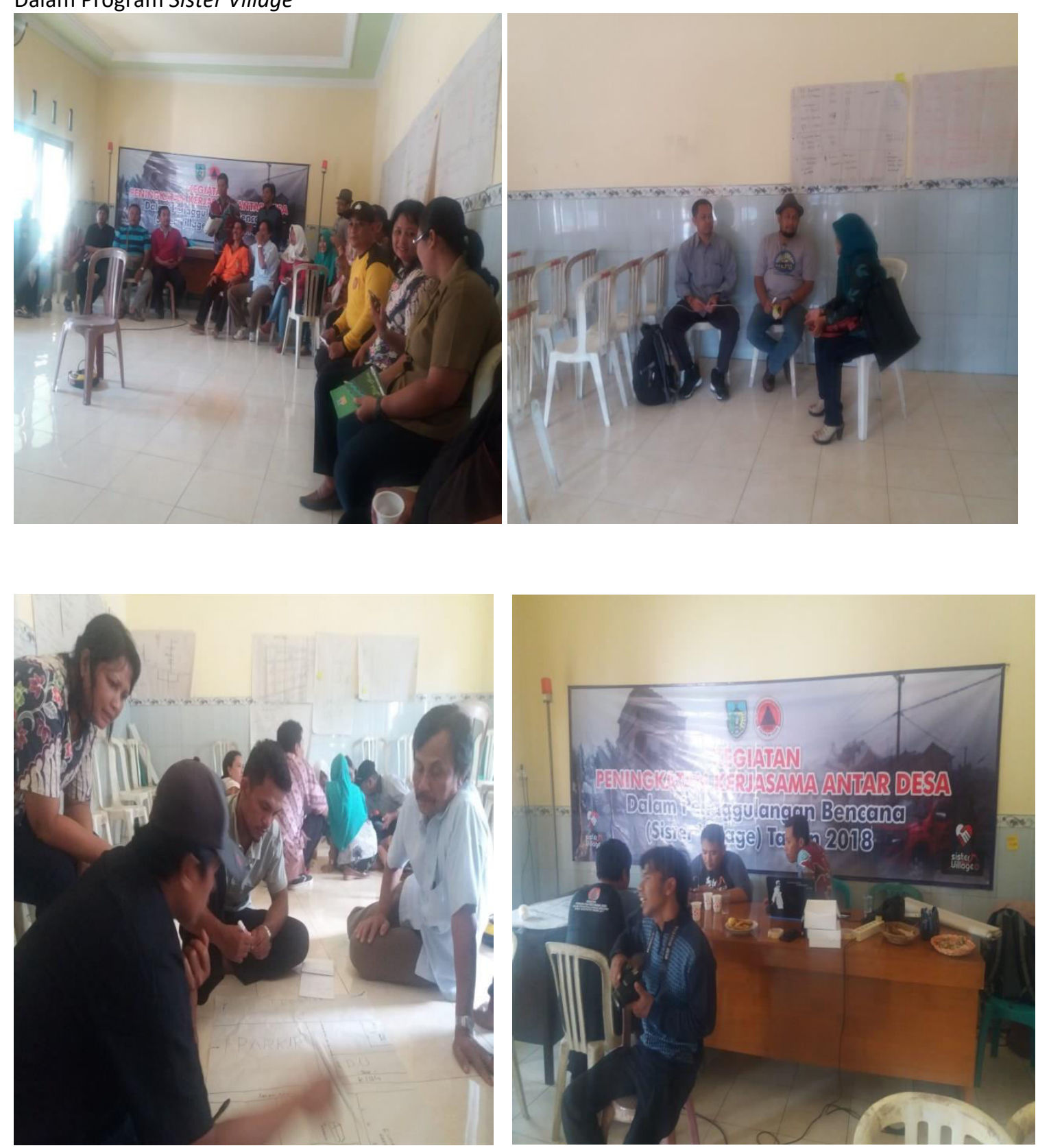

Keterangan: Peneliti Sinau bareng bersama BPBD Kabupaten Kediri, Jangkar Kelud dan Masyarakat Desa Sempu, Pojok dan Segaran dalam Pengembangan Sister Village di KRB Kelud, di kantor desa Segaran Kecamatan Wates tanggal 19 -26 April 2018.

\section{KESIMPULAN}

Pengelolaan bencana di kawasan gunung Kelud pasca erupsi tahun 2014 di wilayah kabupaten Kediri dilakukan secara kolaboratif dan melibatkan berbagai pemangku kepentingan antara lain BPBD Kabupaten Kediri, NGO-Komunitas Jangkar Kelud, Relawan Pengurangan Risiko Bencana baik dari ormas keagaamaam (NU, Muhammadiyah, Kristen, Hindu), tokoh masyarakat, aparatur pemerintah desa di KRB Kelud (Desa Sempu, Sugihwaras kecamatan Ngancar, Desa Besowo, Damarwulan Kecamatan Kepung) dan masyarakat yang tinggal di KRB gunung Kelud. 
Pasca erupsi Gunung Kelud tahun 2014, kegiatan pengelolaan bencana lebih difokuskan pada upaya mitigasi (pengurangan risiko bencana) dan membangun kesiapsiagaan masyarakat di KRB Kelud. Salah satu program yang dikembangkan adalah Desa Bersaudara (Sister Village) yang diadopsi dari kabupaten Magelang yang telah berhasil mengembangkan program Sister village dan mempersaudarakan desa-desa di KRB Gunung Merapi pasca erupsi tahun 2010.

Hingga saat ini program sister village masih berjalan, dan BPBD Kabupaten Kediri bersama Jangkar Kelud sedang mengembangkan sister village dengan pola yang berbeda dengan di Magelang. Jika di Magelang mempersaudarakan 1 desa pengungsi dengan 1 desa penyangga (1:!0, maka pola Sister Village di kabupaten Kediri adalah mempersaudarakan dua desa atau lebih dengan perbandingan 1: 2; yaitu 1 Desa pengungsi dengan 2 desa penyangga. Seperti yang dikembangkan di KRB 2 Kelud yaitu mempersaudarakan Desa Sempu kecamatan Ngancar sebagai desa pengungsi dengan Desa Pojok dan Desa Segaran kecamatan Wates sebagai desa penyangga. Demikian pula di kecamatan Kepung, desa yang dipersaudarakan adalah desa Besowo sebagai desa pengungsi dengan desa Damarwulan dan desa Brumbung sebagai penyangga. Namun dalam pelaksanaannya desa Brumbung menolak mengikuti pengembangan program sister village dan hal ini menjadi tantangan dan kendala tersendiri bagi para pemangku kepentingan dalam melakukan pengelolaan bencana berbasis kapasitas lokal di KRB Gunung Kelud kabupaten Kediri.

\section{DAFTAR PUSTAKA}

Arifin, D., \& Chusairi, A. (2015). Gambaran Pengurangan Risiko Bencana Berbasis Komunitas di Daerah Terdampak Erupsi Gunung Kelud. Jurnal Psikologi Kepribadian Dan Sosial, 4(2), 68-72. Retrieved from www.pengurangan risiko berbasis komunitas

BNPB. (2016, September). Daerah Rawan Bencana di Jawa Timur.

Bourdieu, P. (1986). Distinction (2nd ed.). London: London University Press.

Donovan, A. (2016). Geopower: Reflection on the critical geography of disaster. Progress in Human Geography, 1-24. http://doi.org/10.1177/0309132515627020

Hoffman, S. M., \& Smith, A. O. (2002). Catastrophe \& Culture: The Anthropology of Disaster. (D. W. Schwartz, Ed.) (Scoof of A). Santa Fe, New Mexico: The Scholl of American Research Press.

Humaedi, M. A. (2015). Penanganan Bencana berbasis Perspektif Hubungan Antar Agama dan Kearifan Lokal. Analisa Journal of Social Socience and Religion, 22(2), 213-226. http://doi.org/http://dx.doi/10.18784/analisa.v22i2.211

Indiyanto, A. (2012). Respon Masyarakat Lokal Atas Bencana. (A. Indiyanto \& A. Kuswanjoyo, Eds.) (1st ed.). Yogyakarta: PT Mizan Pustaka bekerja sama Center For Religious \& Cross- Sekolah Pasca Sarjana UGM. Retrieved from http://www.mizan.com

Kelman, I., \& Mather, T. A. (2008). Living with vulcanoes: The sustainable livelihoods approach for volcano-related opportunities. Journal of Vulcanology and Geothermal Research, 172, 189-198. http://doi.org/10.1016/j.volgeores.2007.12.007

Kusumasari, B. (2014). Manajemen Bencana dan kapabilitas Pemerintah Lokal (Pertama). Yogyakarta: Penerbit Gava Media. Retrieved from www.gavamedia.net

Lubis, R. H. (2000). Pengembangan Pola Kemitraan Berbasis Modal Sosial Sebagai Strategi Pemulihan Masyarakat Pasca Bencana. Jurnal Humanioran, 3(5), 1-21.

Sartohadi, J., \& Pratiwi, E. S. (2014). Pengelolaan Bencana Kegunungapian Kelud pada Periode Krisis Erupsi 2014. (J. Sartohadi \& E. S. Pratiwi, Eds.) (1st ed.). Yogyakarta: Pustaka Pelajar.

Windiani, \& Rahmati, F. N. (2016). DIMENSI JURNAL SOSIOLOGI. Dimensi, 9(2), 87-92.

Yusup, Y. (2014). Hidup Bersama Risiko Bencana: Konstruksi Ruang Dalam Perspektif Ruang Relasional. Jurnal Perencanaan Wilayah Dan Kota, 25(1), 59-77. Retrieved from http.artikeljurnal/resikobencana.goegle.com 